\title{
Developing English Front Office Materials for Twelve Grade Students in First Semester
}

\author{
I Gede Febry Wira Pratama ${ }^{1}$ \\ Universitas Pendidikan Ganesha, Indonesia \\ gedepratama889@gmail.com \\ Nyoman Karina Wedanthi ${ }^{2}$ \\ Universitas Pendidikan Ganesha, Indonesia \\ karina.wedhanti@undiksha.ac.id \\ Kadek Sintya Dewi ${ }^{3}$ \\ Universitas Pendidikan Ganesha, Indonesia \\ sintya09@yahoo.com \\ I Gede Budasi ${ }^{4}$ \\ Universitas Pendidikan Ganesha, Indonesia \\ gede.budasi@undiksha.ac.id
}

\begin{abstract}
The purpose of this study was to develop English front office materials for first semester students of class XII at SMK N 2 Singaraja. In the data collection process, researchers used six instruments, namely, Google form for teachers and students, Questionnaire for teachers and front office staff, Checklist for students, and the last instrument is Checklist for expert judges. This research method used the Design and Development (D\&D) model. The results showed that there were 5 topics that needed to be developed, namely; Handling guest arrivals and departures, Handling guest baggage, Bell desk service handling requests, Individual guest check-in handling, Individual guest check-out handling. The conclusion obtained in this study is that there are 5 topics that must be developed into products and each topic contains input, content focus, language focus, and task and the product quality is classified as very good based on the results of two expert judges.
\end{abstract}

Keywords: D\&D method, ESP, English for Front Office.

\section{INTRODUCTION}

Bali which is also called as the Thousand Temples Island has many interesting tourist attractions to visit. Kuta beach, Garuda Wisnu Kencana, Beratan Lake, Bedugul, Kintamani, and Ubud are some of the tourist attractions that are often visited by domestic and foreigners. Bali is famous for its tourist attractions, making many Balinese residents work in the tourism sector. Many Balinese residents work in hotels, restaurants, villas and places related to the tourism sector. Therefore, in Bali there are many tourism schools, especially vocational high school. Vocational High School is a school that prepares students to immediately work in accordance with the majors they take. In vocational education 
students learn something more deeply and are directed at increasing skills to prepare a superior workforce in every job, especially in the field of tourism. To prepare for this, English for specific purposes can be applied. According to Hutchinson \& Waters (1987), English for Specific Purposes (ESP) is a language teaching method, where all learning material and content are designed based on students' needs.

One of the major in tourism school is Front office. According to Agusnawar (2004) Front Office is one of the most important parts of working in a hotel that is responsible for receiving guests, managing rooms, and handling guest complaints. Working as a Front Office staff has a very heavy duty because most of the hotel impression is based on the services provided by Front Office staff. Therefore, working as a Front Office staff must have good language skills, especially in English language. Furthermore, teaching material that will be used in the learning process must have quality to prepare students to work in the tourism sector.

One of the tourism schools that the researcher observed was SMK N 2 Singaraja. $12^{\text {th }}$ grade students in first semester in this school do not yet have a complete textbook about Front office. This fact is obtained based on the questionnaire given by the researcher to teachers and students through Google Form. From the results of the questionnaire, it was found that the teaching materials or books used to teach the Front office were not yet complete, the teacher accessed the material only through the internet and the incomplete textbooks. The book that is used only has a little explanation of Front office lessons which is not good to be used in the learning process. From these problems, the researcher makes a more specific book about Front office because students need to understand how the criteria and functions of Front office staff. The researcher plans to design this book more authentic in order to make students or teachers easy to understand the contents of this book. Therefore, the quality teaching materials makes teachers and students more comfortable to study.

The gap is seen when teaching materials that are of poor quality makes teachers and students feel difficult to understand the material. Students feel less motivated in following the learning process, because the books provided at school are not interesting for students. Without quality teaching materials, teachers get confused in providing material to students which also make students uncomfortable in following the learning process. Teaching materials or books provided must have an explanation of what will be learned. As an example of a book about the Front office, in order to make it easier for students to understand the material it is better if the book included a dialogue about how a Front office staff treats guests. This helps students in reading, listening and reading skills. Besides, this dialogue can be added with illustrations so students feel more interested in learning. The delivery of material from the teacher is faster and students do not feel bored in the learning process. The variety of tasks in the book makes students more challenged to learn, because currently they get assignments that are too monotonous. However, in SMK N 2 Singaraja, especially in 12th grade semester 1 books or materials about the Front office have not met the criteria above, so teachers are often confused to teach Front Office.

Based on the problem found above, the researcher designed a textbook on English for the Front Office for class XII students in the first semester at SMK $\mathrm{N} 2$ Singaraja based on student needs and proficiency goals. This book is 
designed based on a needs analysis that isconducted to students at SMK N 2 Singaraja. According to Robinson, conducting a needs analysis facilitates teachers in obtaining information about the extent of student knowledge, student motivation levels and the needs of individual students. In addition, Agustina, 2014 states that the focus of the skills goal is on four skills namely, reading, writing, listening and speaking. The four skills must be in a book in order to make the delivery of material clear and students are able to develop the four skills. The designed book is focus on improving the four skills, especially listening and speaking skills because these skills are needed in the Front office. Therefore, this book is expected to be able to improve all four skills of students.

English for Specific Purposes (ESP) is teaching English for purposes in certain fields and professionals. According to Hutchinson \& Waters (1987), English for Specific Purposes (ESP) is a language teaching method, where all learning material and content are designed based on students' needs. Another definition is from Richards \& Rodger (2001) who states ESP is language teaching based on student needs, all material taught aims to achieve a goal such as finding a job. To conclude, ESP is a language teaching that focuses on specific goals and based on student needs.

In ESP, needs analysis is one of the important things to do. According to Hutchinson \& Waters (1992), needs analysis is a basis for determining the 'needs' and 'desires' of students about what they will learn. According to Mujtaba, 2014, needs analysis is a procedure that is used as a reference to get information and which is used as a basis for developing materials and curriculum. The curriculum is a planned program that describes how learning will be implemented in educational institutions. According to Hamalik, 2010 the purpose of the curriculum was to provide broad opportunities for students to experience the education and learning process to achieve the target of national education goals in particular and quality human resources in general.

According to Tomlinson (2011), material development is a procedure related to learning designed by teachers, writers, students and lecturers to add information about learning material. In developing materials, which are usually developed can be in the form of books, videos and learning media. According to Nurhamsih \& Syahrial (2017), in developing material, the role of matter must be highly considered. The material must meet several conditions such as, material as a source for presentations, material as a source of activities for students practicing, and material as a source of reference for students.

The similar study was done by Budasi, et al (2015) entitled "Developing English Materials for Front Office Course for the Students of Hotel Accommodation of PPLP Dhyana Pura". The purpose of this study was to develop English language material for front office subjects for PPLP Dhyana Pura Hotel accommodation students and to evaluate the quality of the material developed through the perceptions of expert judges. Research was only limited to product development and expert judgment. This research design used the R\&D model proposed by Sugiyono (2013) and collaborated with Hutchinson \& Waters's Learning-Centered Need Analysis Framework (1987) to be able to analyze student needs. The results found in this study indicated that there were 11 units of English material for the Front Office that had been developed. This finding had 
an important contribution in the development of linguistics in Bali, especially in the field of ESP.

\section{METHOD}

Design

The design of this study used the design and development (D\&D) method which was adapted from the Richey and Klein's model. According to Richey and Klein (2017) the D\&D model is a systematic method of study that includes design, development, and evaluation for the purpose of building an empirical foundation in the manufacture of new products or products that want to be perfected. Puffer et al (2010) stated that there are several data collection processes used in the D\&D model. The data collection process can be seen in Figure 3.1.

Figure 3.1 Procedures D\&D from Puffer

$\left.\left.\left.\begin{array}{c}\text { identify the } \\ \text { problem }\end{array}\right\rangle \begin{array}{c}\text { describe the } \\ \text { objectives }\end{array}\right\rangle \begin{array}{c}\text { design and } \\ \text { develop }\end{array}\right\rangle$ testing $\sum \begin{gathered}\text { evaluate } \\ \text { the results }\end{gathered}$ communicate

From several data collection processes in the D\&D model, researchers only used three processes, namely design, development, and evaluation. This is because researchers lack time and products made only up to the evaluation process.

\section{Setting and Participants}

The subjects of this study were teacher who teaches English for front office at SMK Negeri 2 Singaraja. She was chosen because she is a teacher and head of front office subjects at SMK Negeri 2 Singaraja. In addition, the subjects of this study were students of grade $12^{\text {th }}$ AP4 at SMK Negeri 2 Singaraja who are members of the front office and hotel staff who work as front offices.

\section{Instruments and Data Analysis}

In the data collection process, researchers used six instruments, namely, a Google form for teachers and students, a questionnaire for teachers and front office staff, a checklist for students, and the last instrument is a checklist for expert judges. The questionnaire and checklist were adapted from Basturkmen (2010), Litz (2005), Hutchinson and Waters (2008). In analyzing data, the researcher used qualitative descriptive techniques. According to Sugiani (2014), qualitative descriptive analysis technique is a technique in analyzing or processing data by systematically arranging the results obtained in the form of sentences. Qualitative descriptive techniques were used by the researcher to process data from expert reviews of the content of the learning model. In conducting a qualitative descriptive analysis, the researcher classified information based on qualitative data in the form of input, responses, criticism and suggestions contained in the questionnaire. Then, the results of this analysis were used to improve product quality.

\section{FINDINGS \& DISCUSSIONS} found:

The following are three results based on the data analysis the researcher 


\section{Developing materials based on student's need analysis}

1. The Result of Syllabus Analysis

From the analysis, the results obtained were that there were five topics that needed to be developed for the twelfth-grade students of the first semester. The topics are (1) Handling arrival and departure guest, (2) Handling guest luggage, (3) Request handling of bell desk services, (4) Handling of individual guest check-in, (5) Handling of individual guest check-out.

2. The Result of observation form

The researcher provides questionnaire that aims to find out the content required for each material contained in the product. The questionnaires were distributed to students via Google Form. From the results of the questionnaire, the researcher found that teachers needed books that contained varied assignments, material that provided a lot of practice, and some pictures related to the topics being taught.

3. The Result of Student's Checklist

The result of student's checklist need analysis were collected from 33 students' class XII AP4. Therefore, in the questionnaire there is no more addition of language function either from teachers or from front office staff. To determine the percentage of questionnaire results can be formulated as follows:

Number of students who answered "need" X $\quad$ 100\%

Total number of students

Table 1. The Result of Student's Checklist

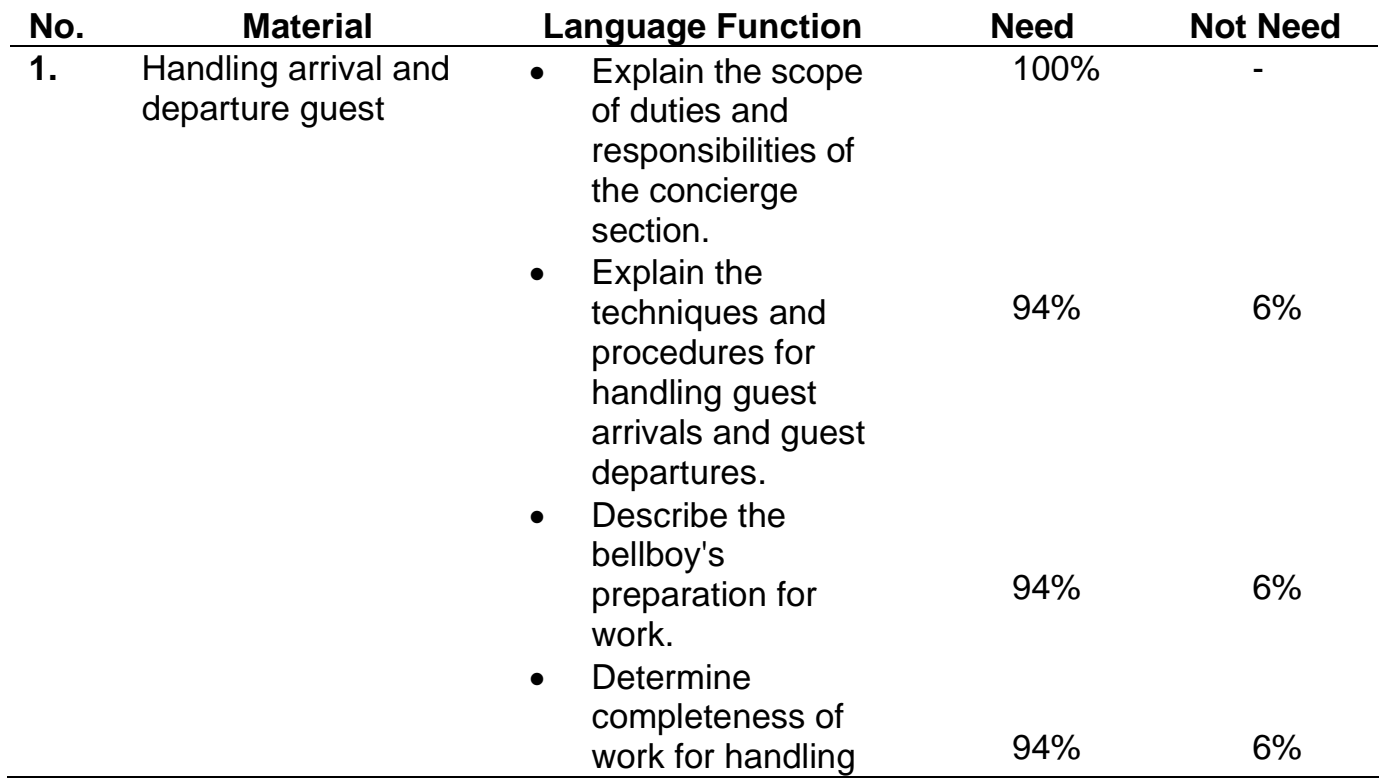


The Art of Teaching English as a Foreign Language, Vol.2 No.1 2021

p-ISSN : 2656-8942, e-ISSN : 2684-8546

DOI: $10.36663 /$ tatefl.v2i1.102

\begin{tabular}{|c|c|c|c|c|}
\hline & & $\begin{array}{l}\text { guest arrivals and } \\
\text { departures. }\end{array}$ & & \\
\hline 2. & $\begin{array}{l}\text { Handling guest } \\
\text { luggage }\end{array}$ & $\begin{array}{l}\text { Explain the } \\
\text { function of handling } \\
\text { guest luggage. } \\
\text { Explain the } \\
\text { techniques and } \\
\text { procedures for } \\
\text { handling guest } \\
\text { luggage. } \\
\text { Describe the types } \\
\text { of guest luggage. }\end{array}$ & $97 \%$ & $3 \%$ \\
\hline 3. & $\begin{array}{l}\text { Request handling of } \\
\text { bell desk services }\end{array}$ & $\begin{array}{l}\text { Describe requests } \\
\text { for bell desk } \\
\text { service. } \\
\text { Describe the } \\
\text { techniques and } \\
\text { procedures for } \\
\text { requesting bell } \\
\text { desk services. } \\
\text { Determine the type } \\
\text { of bell desk service } \\
\text { request. }\end{array}$ & $97 \%$ & $3 \%$ \\
\hline 4 & $\begin{array}{l}\text { Handling of individual } \\
\text { guest check-in }\end{array}$ & 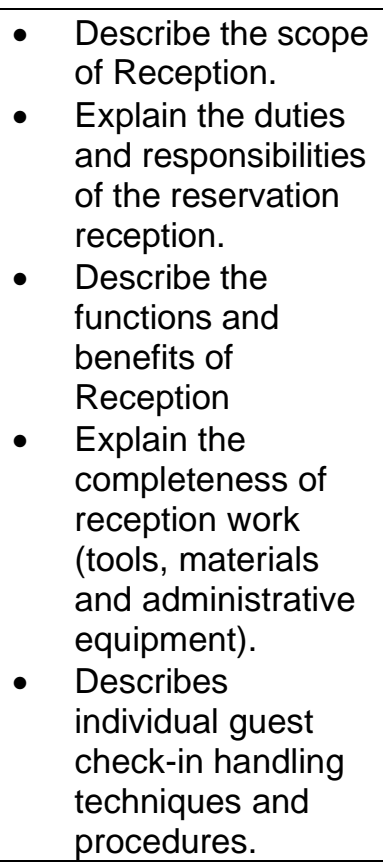 & $\begin{array}{l}97 \% \\
97 \%\end{array}$ & $\begin{array}{l}3 \% \\
3 \%\end{array}$ \\
\hline 5 & $\begin{array}{l}\text { Handling of individual } \\
\text { guest check-out }\end{array}$ & $\begin{array}{l}\text { Describe the } \\
\text { completeness of } \\
\text { individual guest } \\
\text { check-out work } \\
\text { (tools, materials }\end{array}$ & $94 \%$ & $6 \%$ \\
\hline
\end{tabular}


and administrative equipment).

- Describes

individual guest

$6 \%$

check-out handling

techniques and

procedures.

\section{Average}

$96 \%$

$4 \%$

In this study, the researcher conducted a needs analysis with syllabus analysis, questionnaires and student's checklist. Based on the results of the needs analysis, there are several things that are emphasized; 1) The English for front office materials contained in the product should contain several topics specifically for twelve grade students in the first semester. (2) The material consists of information and explanations. This is presented in the form of input, content focus, and vocabulary focus. (3) The material must provide some language expression or language function. It is presented in a language focus which aims to make students know how language works. (4) The material contained in the product must contain four main language skills such as listening, speaking, reading and writing. The four basic skills are presented in the form of tasks. (5) The material must authentic and contain a variety of activities that will build and enhance students' creativity, confidence, and mastery of language skills.

There was study which support this study entitled "Needs Analysis And Material Development In English For Specific Purposes In Relation To English For Islamic Studies" written by Sayed Abudhahir, et al and published by International Journal of Management \& Muamalah in 2015. This study aims to conduct a needs analysis in the process of designing materials to produce English material that is able to help students understand English material for special purposes. The results of this study indicate that there are several things obtained from the needs analysis, such as students needing authentic material to stimulate them naturally in language learning and designing varied assignments(Amiruddin \& Auzair, 2017). This statement supports this research, which is based on need analysis, materials must be authentic and contain varied activities and can increase student creativity. Thus, the researcher designs the content of the material being taught according to the needs of the students.

\section{The Design of English Materials for Front Office Department}

In designing the product, the researcher first creates a blueprint. The blueprint is designed based on the results of the needs analysis questionnaire, the analysis syllabus, and the teaching materials used by the teacher. In a blueprint it consists of input, content focus, language focus, and tasks. Then, after designing the blueprint, the product will be developed based on the product design. There are five units developed in this product. The product developed is focused on four basics English skills, namely listening, speaking, reading, and writing. The exercises provided in the product are based on four basic skills related to front office department. 
In compiling the product, the researcher uses the theory of Hutcington \& Waters (1987). There are 4 important aspects in this theory, namely, input, content focus, language focus, and tasks that will be used by researchers as a guide to develop products. In the input, there are several dialogues and pictures related to the material to be studied. Input aims to stimulate students to be more interested in participating in learning activities. In content focus, there are material and information related to the topic being studied. Then in the focus of language there are grammar reviews, language expressions and vocabulary use with how to pronounce it. Last, tasks are presented based on the four Basic English skills.

The development of this English for front office book aims to present more varied and interesting material, so that students and teachers can more easily carry out the teaching and learning process. In this study, researchers used a design and development model from Richey \& Klein's theory (2017). This research model is determined based on an empirical basis in the manufacture of new products or products that want to be perfected. There was a study which supports this study entitled "Developing Speaking Course Book for English Department Students" written by Sri Kartini, et al in 2019. This research aims to describe the development process, quality, and practicality of the Speaking Course Book entitled Speaking for Daily Activities for English Department students of private universities in West Surabaya. The results showed that through the development process using the DDR Richey and Klein models in collaboration with Richard, the quality of the books was very good. In addition, lecturers and students can also use the book very easily.

\section{The Quality of the Product English Material for Front Office}

The results obtained through the data of the two expert judges are for the product draft reviewed by the first expert judges, a total score of 118 was obtained and for the second expert judges a score of 120 was obtained, while the ideal maximum score was 125. The result show in Table 2 below.

Table 2. The Result of Checklist for Expert Judges

\begin{tabular}{|c|c|c|c|c|c|c|}
\hline \multirow[t]{2}{*}{ No. } & \multirow[t]{2}{*}{ Dimension } & \multirow[t]{2}{*}{ Quality of product } & \multirow{2}{*}{$\begin{array}{c}\text { Relev } \\
\text { ant }\end{array}$} & \multirow{2}{*}{$\begin{array}{l}\text { Irrele } \\
\text { vant }\end{array}$} & \multicolumn{2}{|c|}{ Score (1-5) } \\
\hline & & & & & Judge 1 & Judge 2 \\
\hline \multirow[t]{3}{*}{1.} & $\begin{array}{l}\text { Layout and } \\
\text { Design }\end{array}$ & $\begin{array}{l}\text { The textbook includes a } \\
\text { detailed overview of the } \\
\text { function, structures and } \\
\text { vocabulary that will be } \\
\text { taught in each unit (Litz, } \\
\text { 2005). }\end{array}$ & $\sqrt{ }$ & & 4 & 5 \\
\hline & & $\begin{array}{l}\text { The layout and design } \\
\text { are appropriate and } \\
\text { clear (Litz, 2005). }\end{array}$ & $\sqrt{ }$ & & 5 & 4 \\
\hline & & $\begin{array}{l}\text { The textbook is } \\
\text { organized effectively } \\
\text { (Litz, 2005). }\end{array}$ & $\sqrt{ }$ & & 5 & 5 \\
\hline
\end{tabular}


The Art of Teaching English as a Foreign Language, Vol.2 No.1 2021

p-ISSN : 2656-8942, e-ISSN : 2684-8546

DOI: $10.36663 /$ tatefl.v2i1.102

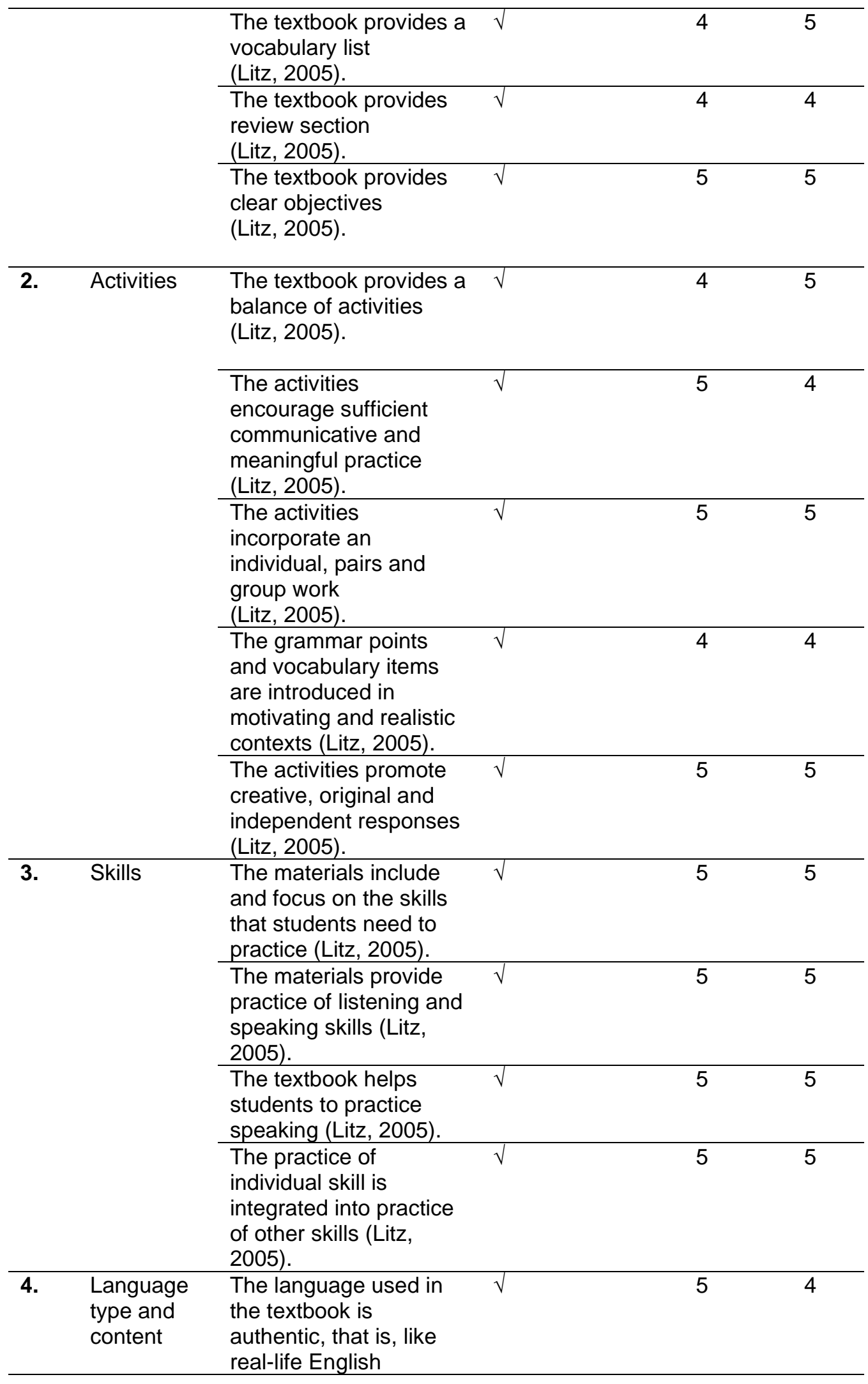


The Art of Teaching English as a Foreign Language, Vol.2 No.1 2021

p-ISSN : 2656-8942, e-ISSN : 2684-8546

DOI: $10.36663 /$ tatefl.v2i1.102

\begin{tabular}{|c|c|c|c|c|c|}
\hline & & (Litz, 2005). & & & \\
\hline & & $\begin{array}{l}\text { The language used is at } \\
\text { the right level for } \\
\text { students' current } \\
\text { English ability } \\
\text { (Litz, 2005). }\end{array}$ & $\sqrt{ }$ & 5 & 5 \\
\hline & & $\begin{array}{l}\text { The progression of } \\
\text { grammar points and } \\
\text { vocabulary items is } \\
\text { appropriate } \\
\text { (Litz, 2005). }\end{array}$ & $\sqrt{ }$ & 5 & 4 \\
\hline & & $\begin{array}{l}\text { The grammar points are } \\
\text { presented with brief and } \\
\text { easy examples and } \\
\text { explanations } \\
\text { (Litz, 2005). }\end{array}$ & $\sqrt{ }$ & 5 & 5 \\
\hline & & $\begin{array}{l}\text { The language functions } \\
\text { exemplify English that } \\
\text { l/my students will be } \\
\text { likely to use in the } \\
\text { future (Litz, 2005). }\end{array}$ & $\sqrt{ }$ & 5 & 5 \\
\hline & $\begin{array}{l}\text { Subject } \\
\text { and } \\
\text { Contents }\end{array}$ & $\begin{array}{l}\text { The subject and } \\
\text { contents of the book are } \\
\text { relevant to student's } \\
\text { need as an English } \\
\text { language learner (s) } \\
\text { (Litz, 2005). }\end{array}$ & $\sqrt{ }$ & 5 & 5 \\
\hline & & $\begin{array}{l}\text { The subject and } \\
\text { contents of the textbook } \\
\text { are generally realistic } \\
(\text { Litz, 2005). }\end{array}$ & $\sqrt{ }$ & 4 & 5 \\
\hline & & $\begin{array}{l}\text { The subject and } \\
\text { contents of the textbook } \\
\text { are interesting, } \\
\text { challenging and } \\
\text { motivating } \\
\text { (Litz, 2005). }\end{array}$ & $\sqrt{ }$ & 5 & 5 \\
\hline & & $\begin{array}{l}\text { There are sufficient } \\
\text { varieties in the subject } \\
\text { and contents of the } \\
\text { textbook (Litz, 2005). }\end{array}$ & $\sqrt{ }$ & 5 & 4 \\
\hline & & $\begin{array}{l}\text { The materials are not } \\
\text { culturally biased and } \\
\text { they do not portray any } \\
\text { negative stereotypes } \\
\text { (Litz, 2005). }\end{array}$ & $\sqrt{ }$ & 4 & 5 \\
\hline & & & & 118 & 120 \\
\hline & erage f & two rates & & 119 & \\
\hline
\end{tabular}

From the results of expert, the contents from two expert judges showed that Gregory's results are 1 which means that the product belongs to a category 
has a very high validity. Based on the result, the calculation obtained the percentage level of product validity of the learning media aspect of the two expert judges is $94.4 \%$ and $96 \%$. This percentage figure can be converted into a scale of 5 , therefore the level of validity of the draft of English for front office learning books is very good. This shows that the product being developed only requires a slight revision from the two expert judges. The two expert judges provided several suggestions and comments to improve the quality of the draft of this book.

There were 4 important aspects that contain in develop this book, namely, input, content focus, language focus, and tasks used by researchers as a guide to develop products. In the input, there were several activities used as a stimulus for students. In this activity students were given examples of dialogue and students analyzed the dialogue, determine the pictures related to the material being studied, and analyzed forms. In the content focus, the researcher developed several materials according to the syllabus. However, in developing this material, researchers did not use all the basic competencies contained in the syllabus, this was because of similar material and did not need to be explained again. In developing this material, researchers used several sources related to front office materials. Therefore, in addition to getting information from each unit in the product, students were able to get more information based on the sources that had been included in the product. In the language focus, the researcher developed the product by adjusting the language function and language expression used in each material or unit. In addition, in the language focus, it also included grammar review, vocabulary used which were completed with how to pronounce it. It helped students understand language expressions, grammar, and vocabulary that were often used in the Front Office department. The last in the task, the researcher developed the product by including several exercises to test students' understanding. The researcher divided the exercises based on four student skills, namely, listening section, speaking section, reading section, and writing section. It aimed to improve the four basics English skills that students will use at work, especially as Front Office staff.

The results of the two expert judges showed that the product was very good quality. This is because the material in the product is in accordance with the analysis of student needs and the content presented varies such as adding examples of conversations, pictures, illustrations and task that are presented in the form of four basic skills in English. This is in line with the research conducted by Andi Asrifan, (2020), this study aims to explore the content that must be included in designed English language materials based on a need analysis in the Tourism Program and to find out the teacher's response to the development of English language material in the Tourism Program. The results of this study indicate that the content to be included in the English language material must contain videos, pictures, and exercises in the form of listening, speaking, writing and reading.

\section{CONCLUSION}


The results of the study could be concluded that the materials needed by Front Office teachers and students were compiled into a set of ESP materials. There are 5 units developed in the product, namely; (1) Handling of arrival and departure guests, (2) Handling of guest luggage, (3) Request handling of bell desk services, (4) Handling of individual guest check-in, (5) Handling of individual guest check-out. Each unit consists of a cover of unit, an input, a content focus, a language focus, and task that presents four basic skills in English (Listening, Speaking, Reading, and Writing). This research begins by analyzing the syllabus and material needs of the front office teachers and students using a questionnaire and check list. Based on the needs analysis, the researcher designed the material by determining basic competencies, achievement indicators, input, content focus, language focus, and assignments. After the product has been designed, the quality of the product is evaluated by expert judges. The quality of the material in the product is assessed based on the criteria for good ESP material proposed by Litz (2005). The results of the two expert judges showed that the total score of the material contained in the product was $94.4 \%$ and $96 \%$. After being converted into an interval score, it shows that the quality of the material in the product being developed is very good. This means that the material being developed is very relevant for use.

\section{REFERENCES}

Ahmed, M. K. (2014). The ESP Teacher: Issues, Tasks and Challenges. English for Specific Purposes World, 15(42), 1-33. http://www.espworld.info/Articles_42/Documents/Ahmed.pdf

Amiruddin, R., \& Auzair, S. M. (2017). Journal of Management \& Muamalah. Journal of Management \& Muamalah, 7(ii).

Asrifan, A., Vargheese, K. J., Syamsu, T., \& Amir, M. (2020). Esp Course Design: The Need Analysis on Tourism Department in Indonesia Vocational High Schools. 3(2), 69-77.

Astuti, N. N. S., Ginaya, G., \& Sadguna, I. G. A. J. (2020). A Hotel Front Desk Receptionist and Catur Paramita Values: A Study of Implementing Local Wisdom in Hospitality Industry. 226 Astuti, (Icss), 479-484. https://doi.org/10.2991/icss-18.2018.100

Baha Hafizullah. (2016). Master of Public Policy and Good Governance Research Methods in Comparative Politics Prof. Dr . Ferdinand Müller-Rommel Assignment: An Introduction of Descriptive Analysis, its advantages and disadvantages. By: Hafizullah Baha Matriculation No. March, 3-14.

Chostelidou, D. (2010). A needs analysis approach to ESP syllabus design in Greek tertiary education: A descriptive account of students' needs. Procedia - Social and Behavioral Sciences, 2(2), 4507-4512. https://doi.org/10.1016/j.sbspro.2010.03.721

Handayani, S. (2016). the Evaluation of English Textbook for Grade Vii of. 328339.

Harsono, Y. M. (2015). Developing Learning Materials for Specific Purposes. TEFLIN Journal - A Publication on the Teaching and Learning of English, 18(2), 169. https://doi.org/10.15639/teflinjournal.v18i2/169-179 
Kartini, S., Lestari, L. A., Munir, A., Surabaya, U. N., \& Surabaya, K. (2019). Developing Speaking Course Book for. 5, 95-108.

Kasumajaya, I., prof. Padmadewi, N., Budasi, I. (2015). Developing English Materials for Front Office Course for the Students of Hotel Accommodation of PPLP Dhyana Pura. Jurnal Pendidikan Bahasa Inggris, 3.

Namira, D. M. (2010). The Important Roles and Activities of Front Office Department At Sahid Jaya Hotel Solo.

Nurhamsih, Y., \& Syahrial, S. (2018). Evaluation of English Teaching Materials used at a Vocational High School Based on Cunningsworth's Checklist. JOALL (Journal of Applied Linguistics \& Literature), 1(1), 33-46. https://doi.org/10.33369/joall.v3i2.6830

Tomlinson, B. (ed.) (2011a). Materials development in language teaching (2nd edn). Cambridge: Cambridge University Press

Tracey, M. W. (2009). Design and development research: A model validation case. Educational Technology Research and Development, 57(4), 553571. https://doi.org/10.1007/s11423-007-9075-0

Widodo, H. P. (2017). Approaches To Needs Analysis in Esp Curriculum Development. The European Journal of Applied Linguistics and TEFL, 127-146. 